American Journal of Animal and Veterinary Sciences 7 (2): 84-91, 2012

ISSN 1557-4555

(C) 2012 Science Publications

\title{
Adaptation to High Grain Diets Proceeds Through Minimal Immune System Stimulation and Differences in Extracellular Matrix Protein Expression in A Model of Subacute Ruminal Acidosis in Non-lactating Dairy Cows
}

\author{
Dionissopoulos, L., M.A. Steele, O. AlZahal and B.W. McBride \\ Department of Animal and Poultry Science, \\ Ontario Agricultural College, University of Guelph, Guelph, ON N1G 2W1, Canada
}

\begin{abstract}
Problem statement: Subacute Ruminal Acidosis (SARA) is a metabolic disorder affecting approximately $20 \%$ of all dairy cattle in North America. Although the presence of SARA has been described for some time, the etiology of the disorder remains uncertain. For example, many animals diagnosed with SARA seem to remodel and adapt their epithelium to accommodate the stresses imposed by SARA, but not before exacting a significant health and economic toll. Specifically, a search is on in which a desire to identify the system and associated pathways that are causative agents in the progression and development of SARA is evident. We hypothesize that adaptation to SARA is facilitated by the immune system. Approach: In order to answer of this question, 4 mature, nonlactating dairy cattle were transitioned from a High Fiber (HF; 0\% grain) diet to High Grain (HG; 65\% grain) diet. Having fed the HG diet for three weeks, the cattle were then transitioned back to the HF diet for an additional three weeks to facilitate adaptation. SARA was diagnosed by $\mathrm{pH}$ data only during the first week and not during the remaining weeks, indicating that adaptation to the HG diet took place within one week. Results: In this study, significant $(\mathrm{p}<0.05)$ extracellular matrix protein changes (COL4A1, LAMB1) were seen during this study indicating a change in matrix architecture to facilitate adaptation. In addition, similar significant $(\mathrm{p}<0.05)$ patterns of expression of inflammatory cytokines and mediators of the LPS-mediated toll-like receptor pathway were seen. Conclusion: These results indicate that the immune system is involved in the adaptation of the rumen epithelium to a HG diet, but to a lesser extent than was previously thought. This is the first time an attempt has been made to link the immune system and wound healing in the adaptation of the bovine rumen to a HG diet.
\end{abstract}

Key words: Subacute Ruminal Acidosis (SARA), adaptation, inflammatory cytokines, immune system, rumen epithelium, immune system, wound healing, extracellular matrix remodeling

\section{INTRODUCTION}

As the degree to which milk production has increased in recent years, higher energy diets for dairy cattle using easily fermentable grains has increased proportionately. High Grain (HG) diets ( $\geq 65 \%$ grain) offer more readily available fermentation by-products such as Volatile Fatty Acids (VFAs) which are used by ruminants for energy production. However, HG diet-fed cattle are at an increased risk for the development of ruminal acidosis, as VFA production can easily exceed the animal's ability for absorption. Subacute Ruminal Acidosis (SARA), diagnosed when rumen $\mathrm{pH}$ drops below 5.6 for more than $3 \mathrm{~h}$ per day, is a common occurrence in dairy cows; an estimated $20 \%$ of all dairy cows have this disorder. Although the precise etiology of SARA remains somewhat elusive, cows so affected display significant morbidity and present decreased feed efficiency and decreased milk production (Plaizier et al., 2008). If SARA develops into chronic metabolic acidosis, hepatic abnormalities, diarrhea, altered blood flow to visceral organs and finally multi-system organ failure can be seen. SARA's financial impact can be as much \$1.12 USD/cow/day (Garrett et al., 1999).

Clinically, as ruminal VFA production increases and acidic load further burdens an overworked gastrointestinal system, physiological homeostasis must be maintained, suggesting an adaptive response. For some time it has been known that chronic, increased VFA production leads to changes in the rumen epithelial milieu, prompting new tissue generation and adaptation in order to meet the increased absorption demands (Mentschel et al., 2001; Gabel et al., 2002). Whenever such bio-physiological events take place, they usually proceed at the expense of other bodily systems. It is the precise triggers of these nutrient- 
partitioning events that are not well characterized and merit further investigation.

Previous experiments have shown that one of the principle methods by which the rumen adapts to the increased VFA production is by increasing the total absorptive surface area of the rumen in dairy cows (Gabel et al., 2002). Delving deeper into the molecular mechanisms behind this phenomenon, we can see that papillae proliferation remains the same, but cellular turnover increases (Goodlad, 1981). This results in an overall increase in cell number and thus papillae hyperplasia. In addition, changes in rumen epithelial integrity are seen in SARA (Steele et al., 2011a) which allow the migration of microbes across the normally protective barrier and help transform a localized immune response to a systemic one (Nagaraja and Titgemeyer, 2007). The migration of microbes and more importantly their antigenic components to the systemic circulation results in a marked increase of circulatory proinflammatory cytokines (Khafipour et al., 2009).

Although many disorders affecting cattle are well characterized, the biochemical pathways responsible for the various etiologies are not. By studying these pathways, we can better understand the biochemical and perhaps the genetic factors that lead to disorders such as SARA. Currently it is not known whether changes in rumen integrity are the result of immunemediated events or due to other changes in gene expression. However, it has been known for some time that increases in grain intake lead to a large and sudden increase in ruminal gram negative bacterial load (Motoi et al., 1993). The harder to digest saccharides derived from cellulose-based HF diets is a less preferred substrate than the more bioavailable sugars derived from fermentable HG diets for bacteria. As obligate anaerobes, gram negative bacteria such as E. coli thrive under these conditions. As a result, lipopolysaccharide (LPS) levels, derived and shed from the cell walls of such bacteria, significantly increase both in the rumen and in the systemic circulation (Motoi et al., 1993). Increases in acidity, coupled with LPS work together to damage the rumen, cause the initial local inflammatory reaction (Gozho et al., 2005) and initiate an immune-mediated cascade that will eventually lead to antigen clearance, ruminal wound healingand the reestablishment of metabolic homeostasis (Thibault et al., 2010).

In order to help characterize the molecular mechanisms surrounding the inflammatory response, a model of SARA has been established in our laboratory. Recently, we (Steele et al., 2011b) demonstrated distinct differences and adaptation in cows fed high grain diets versus cows fed high forage diets. The adaptation and subsequent remodelling in the HG group was demonstrated morphologically after examining histological data from rumen papillae biopsies. During the initial course of SARA, distinct damage to the absorptive layers of the rumen was observed (Steele $e t$ al., 2011a). Examination of the gross pathology revealed epithelial sloughing and adaptation within the weeks that followed. Epithelial degradation is associated with loss of function. In subsequent studies in our laboratory, it has been shown that cows exposed to an acidotic diet undergo adaptation and the reestablishment of homeostasis through changes in rumen epithelial integrity and structure (Steele et al., 2011b). An examination of the cell types present in the new areas indicated that scar formation was kept to a minimum and that actual healing of the erosions had taken place. These events signify that not only proliferative mechanisms were at work, but that the cells had differentiated into their functional progeny.

The objectives of this study are (1) to understand the molecular mechanisms by which the non-lactating cow rumen adapts to facilitate a $\mathrm{HG}$ diet and (2) to determine the extent of immune system involvement in this process. We hypothesize that the effect of feeding a $\mathrm{HG}$ diet on the adaptation of the rumen epithelia was mediated by the immune system by examination of key mediators known to influence or are necessary in the healing of the gastro-epithelia following acidotic injury.

\section{MATERIALS AND METHODS}

Animals and management: The specifics of the experimental treatments involved in this study have been described previously (Steele et al., 2011b). Briefly, four non-lactating Holstein cows $(760 \pm 30 \mathrm{~kg}$ $\mathrm{BW}$ ) were used to detect a $30 \%$ treatment difference with $80 \%$ statistical power (Berndtson, 1991). Prior to the commencement of the experiment, all protocols were reviewed and approved by the University of Guelph Animal Care Committee using endpoints set forth by the Canadian Council on Animal Care. One week prior to the start of the study, the animals were fed a High Forage (HF) diet mainly of dry hay $(90.6 \%$ dry matter, $114 \mathrm{~g}$ crude protein/kg dry matter, $600 \mathrm{~g}$ neutral detergent fiber/kg dry matterand $69 \mathrm{~g}$ starch/ $/ \mathrm{kg}$ dry matter). The duration of the experiment lasted 7 weeks. During the experimental period, the animals were fed either a the HF diet, or a high grain diet $35 \%$ chopped hay $65 \%$ mixed grain which was composed of $88.9 \%$ dry matter, $117 \mathrm{~g}$ crude protein $/ \mathrm{kg}$ dry matter, $307 \mathrm{~g}$ neutral detergent fiber/kg dry matter, $504 \mathrm{~g}$ nonfiber carbohydrate/kg dry matterand $409 \mathrm{~g}$ starch/kg dry matter. The chopped hay was fed in equal portions at 08:00 and 16:00. The grain pelleted diet (40\% ground wheat, $40 \%$ ground barley, $20 \%$ ground corn) was fed in three equal portions at 08:00, 12:00and 16:00 in order to induce acidosis. This feeding strategy has 
previously been described by our laboratory (Keunen $e t$ al., 2002) and meets the energy and protein requirements recommended by the National Research Council (NRC, 2001).

Just prior to transitioning from the HF to the HG diet, a baseline set of measurements were taken (Day 0 ). Following the administration of the HG diet for three weeks, the animals were switched back to the HF diet, in order to demonstrate physical adaptation of the rumen to diets of differing grain levels. In order to confirm the development and the diagnosis of SARA, rumen $\mathrm{pH}$ was measured during the last 2 days of each experimental week (AlZahal et al., 2007).

Rumen papillae biopsies, RNA and protein extraction: Papillae were harvested from the ventral sac of the rumen at the end of experimental weeks $0,1,3$, 4 and 6 based on methods previously described (Kelly et al., 1993). After partially evacuating the rumen of its fluid and solid contents, approximately $150 \mathrm{mg}$ of papillae was cut from the rumen wall with surgical scissors. This tissue was subsequently washed 20 times in ice-cold PBS, placed in liquid nitrogenand then stored at $-80^{\circ} \mathrm{C}$ until the RNA and protein could be isolated.

Total RNA was isolated as previously described by Steele et al. (2012) using an RNeasy midi kit (Qiagen, Missisauga, Ontario, Canada). RNA concentration was determined using a Nano Drop (ND-1000, Nano Drop Technologies and Wilmington DE). RNA was subsequently treated with a DNase (Invitrogen, Burlington, Ontario, Canada) and its quality was assessed using an Agilent 2100 Bioanalyzer (Agilent Technologies Inc., Palo Alto, CA) and the RNA 6000 Nano kit (Caliper Life Sciences, Mountain View, CA). Five microgram aliquots of RNA were used to create cDNA. Quantitative (qPCR) using iTaq SYBR Green (Bio-Rad Laboratories) qPCR analysis was performed in duplicate using the ABI Prism 7000 (Applied Biosystems). The gene symbol, name, accession number, sequence, amplicon sizeand primer efficiency is presented in Table 1. Primers were chosen based upon a similar model of SARA and immune function in our laboratory. All primers were exon-spanningand were designed using NCBI/PrimerBLAST Primer Express (http://www.ncbi.nlm.nih.gov/tools/primerblast/) and bovine sequences listed in GenBank (National Center for Biotechnology Information, Bethesda, MD). All amplification products were verified using BLASTN in NCBIand their dissociation curves were generated at the end of amplification to verify the presence of a single product. On the basis of previous experimental protocols (Steele et al., 2011a), GAPDH was determined to be the most stable housekeeping gene in the rumen papillae and was thus used in this study. For each week, the relative mRNA expression of genes was calculated using the inverse of qPCR efficiency raised to Delta $\mathrm{Ct}(\Delta \mathrm{Ct})$ using the Pfaffl method (Pfaffl et al., 2004). The HF cattle values were pooled for each experimental week to create a control value to which each HG sample was normalized for determination of relative mRNA expression, as previously described (Xue et al., 2010).

Total protein from rumen papillae samples was extracted using the ReadyPrep Protein Extraction Kit (Bio-Rad Laboratories). Tissue was homogenized and centrifuged at $13,000 \mathrm{~g}$ for $25 \mathrm{~min}$ at $4^{\circ} \mathrm{C}$. The total protein concentrations were determined using the Bio-Rad Protein Assay Kit. Electrophoresis of proteins was performed using glycerol-based SDS-polyacrylamide gels $(12 \%)$ and and subsequently transferred to polyvinylidene difluoride membranes (Millipore). Immunoblotting was carried out using the SNAP i.d. System vacuum (www.Millipore.com). Using a similar rationale as was done with qPCR, the protein targets were chosen based upon results obtained using a similar model of SARA and immune function in our laboratory. All primary antibodies were obtained from Santa Cruz Biotechnology (www.scbt.com) (EGF, cat \#sc-1343; NFATC2, cat. \#sc13034; ATPS, cat \#49162; COL4A1, cat. \#sc-9301; FN1, cat. \#sc-6952; LAMB1, cat. \#sc-23410; MCT1, cat \#sc50325. After incubation with the necessary secondary antibodies, targets were detected using the enhanced chemiluminescence method (ECL Advance Western Blotting Detection Kit; GE/Amersham,), visualized using the ChemiGenius2 Bioimaging system (Syngene; Cambridge, United Kingdom)and quantified (Gene Tools software; PerkinElmer). For quality control purposes, equal loading was confirmed using alpha tubulin as a control (cat. \#sc-31782).

Statistical analysis: In order to detect relevant statistical treatment-induced differences in protein and RNA expression, the data analysis for this paper was generated using [SAS/STAT] software, Version 9.1 of the SAS System for Windows. Copyright (C) 20022003, SAS Institute Inc.

$$
\begin{aligned}
Y_{i j}=\mu & +W_{i}+D_{j}+(D \times P)_{i j}+\varepsilon_{i j} \text { where } \\
Y_{k l} & =\text { The dependent variable } \\
\mu & =\text { The overall mean } \\
W_{k} & =\text { The fixed effect of week }(\mathrm{i}=1,2,3,4,5,6) \\
D_{1} & =\text { The fixed effect of forage/grain }(j=1,2) \\
W \times D & =\text { The week x forage/grain level }[(\mathrm{ij})=1,2,3, \\
& 4,5,6] \\
\varepsilon_{\mathrm{kl}} & =\text { The random residual error }
\end{aligned}
$$

This model accounts for the repeated measures on each cow using previously described methodologies (Wang and Goonewardene, 2004). 
American J. Animal \& Vet. Sci., 7 (2): 84-91, 2012

\begin{tabular}{|c|c|c|c|c|c|}
\hline Gene symbol & Name & Gen bank accession & Primer $\left(5^{\prime}-3^{\prime}\right)$ & Amplicon size (bp) & Efficiency (\%) \\
\hline ATP5A1 & $\begin{array}{l}\text { Bos taurus ATP synthase, } \\
\text { H+ transporting, } \\
\text { mitochondrial F1 } \\
\text { complex, alpha } \\
\text { subunit } 1\end{array}$ & NM_174684.2 & $\begin{array}{l}\text { F-GGCCATGAAACAGGTGGCAGG } \\
\text { R-GCTCAGTCAAACGCACACCACG }\end{array}$ & 78 & 97 \\
\hline BCL10 & $\begin{array}{l}\text { Bos taurus B-cell } \\
\text { CLL/lymphoma } 10\end{array}$ & NM_001078028.1 & $\begin{array}{l}\text { F-CAAAGGACTGGATACCCTGGTCGAA } \\
\text { R-GGCTCACAGCTGCTACATTTCAGTC }\end{array}$ & 92 & 89 \\
\hline COL4A1 & $\begin{array}{l}\text { Bos taurus collagen, } \\
\text { type IV, alpha } 1\end{array}$ & NM_001166511.1 & $\begin{array}{l}\text { F-GAGTCCAGGGTTTCCAGGCGAC } \\
\text { R-CCCAACGGTCCCGTGCCAAT }\end{array}$ & 104 & 87 \\
\hline FN1 & $\begin{array}{l}\text { Bos Taurus } \\
\text { fibronectin } 1\end{array}$ & NM_001163778.1 & $\begin{array}{l}\text { F-CCAGCACAGCCACTTCCGTG } \\
\text { R-GGGCGTCAGGTGCTGTGGTC }\end{array}$ & 78 & 93 \\
\hline IKKA/CHUK & $\begin{array}{l}\text { Bos taurus conserved } \\
\text { helix-loop-helix } \\
\text { ubiquitous kinase }\end{array}$ & NM_174021.2 & $\begin{array}{l}\text { F-GAATCTCTGGAACAGCGCGCAA } \\
\text { R-ACCATCTCCGTGCTGTCGCT }\end{array}$ & 120 & 94 \\
\hline IL1 & $\begin{array}{l}\text { Bos taurus interleukin } \\
1 \text {, beta }\end{array}$ & NM_174093.1 & $\begin{array}{l}\text { F-TGAACCGAGAAGTGGTGTTCTGCAT } \\
\text { R-CAGCTGCAGGGTGGGCGTAT }\end{array}$ & 145 & 87 \\
\hline IRAK1 & $\begin{array}{l}\text { Bos taurus interleukin } \\
-1 \text { receptor-associated } \\
\text { kinase } 1\end{array}$ & NM_001040555.1 & $\begin{array}{l}\text { F-GTGGATCAACCGCAACGCCC } \\
\text { R-GGGAGGGTGCCAAGCAGTGA }\end{array}$ & 98 & 85 \\
\hline LAMB1 & $\begin{array}{l}\text { Bos taurus laminin, } \\
\text {,beta } 1\end{array}$ & NM_001206519.1 & $\begin{array}{l}\text { F-ACGACATTTGCTCCAAACCGCC } \\
\text { R-AGCTGGACGGAATGTCTTGAAGGT }\end{array}$ & 89 & 91 \\
\hline PCNA & $\begin{array}{l}\text { Bos taurus proliferating } \\
\text { cell nuclear antigen }\end{array}$ & NM_001034494.1 & $\begin{array}{l}\text { F-CGTGAACCTCACCAGCATGTCCA } \\
\text { R-AGTGCCAACGTGTCCGCGTTAT }\end{array}$ & 99 & 89 \\
\hline TNFA & $\begin{array}{l}\text { Bos taurus tumor } \\
\text { necrosis factor }\end{array}$ & NM_173966.2 & $\begin{array}{l}\text { F-CCCTCCATCAACAGCCCTCTGG } \\
\text { R-TGATGTCGGCTACAACGTGGGC }\end{array}$ & 135 & 91 \\
\hline NFATC2 & $\begin{array}{l}\text { Bos taurus nuclear } \\
\text { factor of activated } \\
\text { T- cells, cytoplasmic, } \\
\text { calcineurin-dependent } \\
2 \text {, transcript variant } 3\end{array}$ & XM_608872.3 & $\begin{array}{l}\text { F-ACGGCGGCCAGCAGATGATT } \\
\text { R-AGCATGTTAGGCTGGCTCTTGTCT }\end{array}$ & 110 & 98 \\
\hline GAPDH & $\begin{array}{l}\text { Bos Taurus } \\
\text { glyceraldehydes- } \\
\text { 3-phosphate } \\
\text { dehydrogenase }\end{array}$ & NM_001034034.1 & $\begin{array}{l}\text { F-TGGAAAGGCCATCACCATCT } \\
\text { R-CCCACTTGATGTTGGCAG }\end{array}$ & 129 & 84 \\
\hline
\end{tabular}

\section{RESULTS}

In a previous study using this model, Steele et al. (2011b) showed the successful sub-clinical reduction in rumen $\mathrm{pH}$ ( $<5.8$ for greater than $3 \mathrm{~h}$ per day) using a high grain diet. In addition, they suggest that the decreases in $\mathrm{pH}$ were due mainly to the overproduction of SCFAs. In order to demonstrate a physiological adaptation to this condition, we see in this study that the monocarboxylate transporter, MCT1, increases 1.7 fold when the HG diet was applied and returned to normal when the HG diet was discontinued $(\mathrm{p}<0.05$; Table 2$)$.

Protein expression: The expression of the different proteins tested in this study is presented in Table 2. Of the proteins tested for immune-reactivity, the Extracellular Matrix (ECM) proteins collagen IV, laminin and the Transporter protein (MCT1) significantly changed over time $(\mathrm{P}<.05)$ and thus a positive treatment-effect was demonstrated. In addition, the time course of EGF expression seems to correlate with the expression of COL4A1, ATPS and NFATc2.
FN1 did not show a correlation with any of the proteins tested (Table 3). However, the down regulation seen with COL4A1 did correlate with NFATC2 and EGF $(\mathrm{p}<0.05$; Table 3$)$.

qPCR: mRNA expression is presented in Table 4. All the transcription factors and cytokines tested in this study peaked between weeks 2-3 and showed similar responses $(\mathrm{P}<0.05)$ during the time course of this experiment. Of particular note is that the expression of the pro-inflammatory cytokines TNFA and IL1 seem to mirror the expression of the other immune system factors tested. Differential expression of the ECM proteins did not differ over time. However, all mRNA expression seemed to follow the same pattern. A correlational examination of mRNA expression reveals a direct relationship between members or affiliates of the TLR4 pathway (Table 5). Such members include, but are not limited to, IL1, TNF $\alpha$, IRAK1 and BCL10. In addition, the up or down regulation of the ECM genes were significantly correlated to one another (LAMB1, COL4A1 and FN1). 
American J. Animal \& Vet. Sci., 7 (2): 84-91, 2012

Table 2: Protein expression values and contrast significance levels for cattle fed either the High-Forage (HF) diet or the High-Grain (HG) diet. Asterisks represent values differing significantly from baseline $(p<0.05$. Cows $(n=4)$ were fed the baseline HF diet for one week (period A), the HG diet for 3 weeks (period BC) and then returned to the HF diet (period DE) for three additional weeks.

\begin{tabular}{|c|c|c|c|c|c|c|c|c|c|c|}
\hline & \multirow{2}{*}{$\begin{array}{l}\text { Baseline } \\
------- \\
\text { A } \\
\text { Week } 0\end{array}$} & \multicolumn{2}{|c|}{ High grain } & \multicolumn{2}{|c|}{ High forage } & \multirow[b]{2}{*}{ SE } & \multicolumn{4}{|c|}{$\mathrm{P}$ (Interaction) } \\
\hline & & $\begin{array}{l}\text { B } \\
\text { Week 1 }\end{array}$ & $\begin{array}{l}\text { C } \\
\text { Week } 3\end{array}$ & $\begin{array}{l}\mathrm{D} \\
\text { Week } 5\end{array}$ & $\begin{array}{l}\text { E } \\
\text { Week } 6\end{array}$ & & $\begin{array}{l}\text { A vs. } \\
\text { BCDE }\end{array}$ & $\begin{array}{l}\text { A vs. } \\
\text { BC }\end{array}$ & $\begin{array}{l}\text { A vs. } \\
\text { DE }\end{array}$ & $\begin{array}{l}\text { A vs. } \\
\text { DE }\end{array}$ \\
\hline$\overline{\text { LAMB1 }}$ & 2.59 & 2.69 & $1.17^{*}$ & 1.53 & $1.31 *$ & 0.44 & 0.08 & 0.23 & 0.05 & 0.25 \\
\hline FN1 & 0.38 & 0.11 & 0.73 & 0.15 & 0.25 & 0.13 & 0.67 & 0.82 & 0.32 & 0.14 \\
\hline EGF & 1.92 & 1.45 & 2.61 & 2.15 & 1.44 & 0.42 & 0.97 & 0.77 & 0.72 & 0.43 \\
\hline COL4A1 & 10.09 & 7.21 & $6.67 *$ & $4.81 *$ & $3.96^{*}$ & 1.56 & 0.01 & 0.06 & 0.01 & 0.06 \\
\hline ATPS & 4.62 & 4.34 & 3.79 & 2.53 & 2.62 & 0.99 & 0.22 & 0.62 & 0.09 & 0.12 \\
\hline NFATC2 & 2.47 & $1.29 *$ & 2.26 & 1.93 & 1.57 & 0.37 & 0.11 & 0.14 & 0.13 & 0.94 \\
\hline MCT1 & 1.93 & $3.26^{*}$ & 1.82 & 1.19 & 1.83 & 0.35 & 0.82 & 0.19 & 0.37 & 0.02 \\
\hline
\end{tabular}

Table 3: Pearson correlation table for proteins in Table 2. Asterisks represent differing significance levels $(*=\mathrm{p}<0.05 ; * *=\mathrm{p}<0.01 ; * * *=$ $\mathrm{p}<0.001)$.

\begin{tabular}{|c|c|c|c|c|c|c|c|}
\hline & LAMB1 & FN1 & EGF & COL4A1 & ATPS & NFATC2 & MCT1 \\
\hline$\overline{\text { LAMB1 }}$ & & & & $*$ & $*$ & & \\
\hline \multicolumn{8}{|l|}{ FN1 } \\
\hline EGF & & & & $*$ & ** & $* *$ & \\
\hline COL4A1 & $*$ & & $*$ & & $* * *$ & $*$ & \\
\hline ATPS & $*$ & & $* *$ & $* * *$ & & $* *$ & $*$ \\
\hline NFATC2 & & & $* *$ & $*$ & $* *$ & & \\
\hline MCT1 & & & & & $*$ & & \\
\hline
\end{tabular}

Table 4: Least square means qPCR expression values and contrast significance levels from cows fed either the HF or HG diet. Asterisks represent values differing significantly from baseline $(\mathrm{p}<0.05)$. Cows $(\mathrm{n}=4)$ were fed the baseline HF diet for one week (period A), the HG diet for 3 weeks (period BC) and then returned to the HF diet (period DE) for three additional weeks.

\begin{tabular}{|c|c|c|c|c|c|c|c|c|c|c|}
\hline & \multirow{2}{*}{$\begin{array}{l}\text { Baseline } \\
------ \\
\text { A } \\
\text { Week } 0\end{array}$} & \multicolumn{2}{|l|}{ High grain } & \multicolumn{2}{|l|}{ High forage } & \multirow[b]{2}{*}{$\mathrm{SE}$} & \multicolumn{4}{|c|}{$\mathrm{P}$ (Interaction) } \\
\hline & & $\begin{array}{l}\text { B } \\
\text { Week 1 } \\
\end{array}$ & $\begin{array}{l}\text { C } \\
\text { Week } 3\end{array}$ & $\begin{array}{l}\text { D } \\
\text { Week } 4 \\
\end{array}$ & $\begin{array}{l}\text { E } \\
\text { Week } 6\end{array}$ & & $\begin{array}{l}\text { A vs. } \\
\text { BCDE }\end{array}$ & $\begin{array}{l}\text { A vs. } \\
\text { BC }\end{array}$ & $\begin{array}{l}\text { A vs. } \\
\text { DE }\end{array}$ & $\begin{array}{l}\text { A vs. } \\
\text { DE }\end{array}$ \\
\hline LAMB1 & 1 & 0.98 & 1.15 & 0.96 & 0.89 & 0.44 & 0.96 & 0.51 & 0.45 & 0.09 \\
\hline FN1 & 1 & 1.07 & 1.36 & 0.87 & 0.9 & 0.17 & 0.81 & 0.33 & 0.58 & 0.08 \\
\hline EGF & 1 & 0.83 & 0.80 & 1.13 & 0.59 & 0.16 & 0.28 & 0.27 & 0.40 & 0.73 \\
\hline COL4A1 & 1 & 1.10 & 1.24 & 1.2 & 1.22 & 0.21 & 0.25 & 0.34 & 0.25 & 0.79 \\
\hline ATPS & 1 & 0.94 & 0.96 & 1.23 & 1.22 & 0.17 & 0.57 & 0.75 & 0.19 & 0.05 \\
\hline NFATC2 & 1 & $0.62 *$ & 0.87 & 1.05 & 0.84 & 0.08 & 0.16 & 0.04 & 0.64 & 0.04 \\
\hline PCNA & 1 & 0.83 & 0.95 & 0.95 & 1.05 & 0.10 & 0.58 & 0.31 & 0.99 & 0.21 \\
\hline IRAK1 & 1 & 0.76 & 0.90 & 1.16 & 1.01 & 0.11 & 0.73 & 0.18 & 0.45 & 0.02 \\
\hline IL1 & 1 & 0.51 & $3.10^{*}$ & $3.12 *$ & 2.58 & 0.78 & 0.11 & 0.36 & 0.05 & 0.16 \\
\hline TNFA & 1 & $0.64 *$ & 1.07 & 1.08 & 0.8 & 0.13 & 0.40 & 0.28 & 0.65 & 0.42 \\
\hline BCL10 & 1 & 0.76 & 0.99 & 1.32 & 1.02 & 0.14 & 0.85 & 0.43 & 0.27 & 0.03 \\
\hline
\end{tabular}

Table 5: Pearson correlation table for genes in table 4. Asterisks represent differing significance levels $(*=\mathrm{p}<0.05 ; * *=\mathrm{p}<0.01 ; * * *=$

\begin{tabular}{|c|c|c|c|c|c|c|c|c|c|c|c|}
\hline & LAMB1 & FN1 & EGF & COL4A1 & ATPS & NFATC2 & PCNA & IRAK1 & IL1 & TNFA & BCL10 \\
\hline$\overline{\text { LAMB1 }}$ & & $* * *$ & & $* * *$ & & & & & & $* *$ & \\
\hline FN1 & $* * *$ & & & $* *$ & & & & & & & \\
\hline EGF & & & & & $*$ & & & $* *$ & & $* *$ & \\
\hline COL4A1 & $* * *$ & $* *$ & & & $* * *$ & & $*$ & $* * *$ & $* *$ & * & $* *$ \\
\hline ATPS & & & $*$ & $* * *$ & & & & $* * *$ & $*$ & $*$ & $* * *$ \\
\hline NFATC2 & & & & & & & & $*$ & & $* *$ & $*$ \\
\hline PCNA & & & & $*$ & & & & $* *$ & & $*$ & \\
\hline IRAK1 & & & $* *$ & $* * *$ & $* * *$ & $*$ & $* *$ & & * & $* *$ & $* * *$ \\
\hline IL1 & & & & $* *$ & $*$ & & & $*$ & & $* *$ & $* *$ \\
\hline TNFA & $* *$ & & $* *$ & $*$ & $*$ & $* *$ & $*$ & $* *$ & $* *$ & & $*$ \\
\hline BCL10 & & & & $* *$ & & $* *$ & & $* * *$ & $* *$ & $*$ & \\
\hline
\end{tabular}


American J. Animal \& Vet. Sci., 7 (2): 84-91, 2012

\section{DISCUSSION}

This study was conducted to determine the extent to which the immune system plays a role in the ability of the bovine rumen epithelium to adapt to a HG challenge. High grain, typically fed to increase production in the most cost-effective way, results in some untoward side effects. Among the costliest and most severe is the development of sub-acute ruminal acidosis or SARA. Part of the problem lies in its inherent difficulty of detection. An animal affected with SARA can be either misdiagnosed or go undiagnosed for a very long time. This clinical condition can weigh heavily in production dollars. The most recent estimates of the cost of SARA run as high as \$1.20/USD/Day/cow (Garrett et al., 1999; Plaizier et al., 2008). Although the presence of SARA has been known for some time, the molecular mechanisms that foster its development remain unknown. By studying these mechanisms and the systems that govern them, we can better understand the etiology of this disorder and hopefully develop viable treatment modalities to combat it.

As with all tissues, wound healing in the rumen following an acidotic challenge likely proceeds in the same way. That is, it is made up of three distinct timedependent phases: Inflammation, proliferation and remodeling (Schreml et al., 2010). How long each phase lasts depends on the severity of the insult that was the initiating factor. For example, in the gastrointestinal tract, full-thickness, transmural wounds take the longest to heal. In addition, the presence of microbial pathogens may further lengthen the wound healing process. Most importantly, the success of a healed tissue depends on its functionality, i.e., the prevention of scar tissue formation and normal tissue restitution (Menke et al., 2007). In our model, microscopic images revealed that the extent of damage to the rumen following a HG challenge was limited to epithelial sloughing and to a lesser extent tight junction degradation (Steele et al. 2011a); this sloughing was restored with an epithelium that was adapted to accommodate the HG challenge. Since the rumen epithelium became slightly permeable, it is possible that some microorganisms penetrated to the submucosal layers, since elevated levels of Lipopolysaccharide Binding Protein (LPSBP) were detected using the same model in subsequent experiments (Li et al., 2012; Steele et al., 2012). Because of the limited extent of pathogenic organisms and LPS infiltration, the inflammatory phase of the wound healing cascade was extremely limited. However, PCR data indicates the only cytokine which was increased in response to the HG challenge was IL1 and its correlate IRAK1, which is consistent with a small, local inflammatory reaction. This small increase in IL1 likely involved the recruitment of local inflammatory cells in order to clear any pathogenic organisms. Yet contrary to what might be expected, both TNF $\alpha$ and NFATC2 were decreased significantly during the same period. In addition to its effects as a proinflammatory cytokine, TNF $\alpha$ is associated with the modulation of metaloproteinases which degrade and contribute to matrix remodeling (Han et al., 2001). Moreover, in this context, NFATC2 is associated with the integrity and barrier function of the rumen epithelium by modifying the turnover rate of gap/tight junction proteins (Crabtree and Olson, 2002). Since type IV collagen and laminin 1 are present in mature functional tissue, their degradation must proceed in harmony with the relaxation of tight junction integrity if tissue remodeling is to take place. In Tables 2 and 4, the rate of collagen IV expression is seen to decrease over time and starts well into the period delineated by the HG challenge. These results agree with the cascade mediators that were assayed. It appears that these degradation events are necessary in order to firstly degrade and then remodel the extracellular matrix upon which the epithelium rests. Furthermore, the Pearson correlation tables (Tables 3 and 5) indicate a significant degree of association between energy availability and the ECM proteins collagen IV, fibronectin 1 and laminin $\beta 1$. This architectural rearrangement must be a necessary step in the adaptation or remodeling of the rumen epithelium to $\mathrm{HG}$ diets. Interestingly, although not specifically affected by treatment, many factors assayed either by immunoblot or qPCR were significantly correlated. This result is evident in the relationships indicated for the matrix proteins, cytokines and members of the LPSmediated TLR4 signal cascade that were seen in a previous study (unpublished data).

Part of the remodeling or adaptation in this model involved the necessary upregulation of transporters that regulate $\mathrm{pH}$ and the influx of SCFAs produced as a result of the rapid increase in highly fermentable grains from the HG diet. Table 2 indicates that the levels of the monocarboxylate transporter MCT1 were immediately increased upon administration of the HG diet and returned to normal slightly thereafter. This result agrees with previous experiments by Steele et al. (2011a; 2011b; 2012) who found that butyrate (a monocarboxylate anion) levels rapidly increase the first week following a $\mathrm{HG}$ challenge and steadily decrease over time.

\section{CONCLUSION}

Prior to the commencement of this experiment, we hypothesized that the epithelial remodeling that was 
seen previously was mediated by the immune system. Indeed, we saw several inflammatory mediators respond to the treatment in addition to the remodeling of the ECM to accommodate the HG diet. However, the response from the immune system was extremely limited as compared to other experimental models of wound healing in the gastrointestinal system. Results in this study indicate that the inflammatory response was limited to local effects. Evidently, the remodeling or adaptation that was seen in this model is a muted form of the wound healing cascade and a function of the subclinical nature of this disorder. Ultimately, the local response serves to prepare the rumen epithelium for adaptation to a $\mathrm{HG}$ diet.

\section{ACKNOWLEDGEMENT}

The researchers would like to thank the staff at the Ponsonby Sheep Research Station, University of Guelph, for their assistance in animal husbandry and in technical matters. Financial support for this study came from the Ontario Ministry of Agriculture, Food and Rural Affairs (OMAFRA) and the Natural Sciences and Engineering Research Council of Canada (NSERC; BWM) and is gratefully appreciated.

\section{REFERENCES}

NRC, 2001. Nutrient Requirements of Dairy Cattle. National Academy of Sciences. 7th Edn., Washington, ISBN-10: 0309069971, pp: 54.

AlZahal, O., B. Rustomo, N.E. Odongo, T.F. Duffield and B.W. McBride, 2007. Technical note: A system for continuous recording of ruminal $\mathrm{pH}$ in cattle. J. Animal Sci., 85: 213-217. DOI: 10.2527/jas.2006-095

Berndtson, W.E., 1991. A simple, rapid and reliable method for selecting or assessing the number of replicates for animal experiments. J. Anim. Sci., 69: 67-76. PMID: 2005039

Crabtree, G.R. and E.N. Olson, 2002. NFAT signaling: Choreographing the social lives of cells. Cell, 109: S67-S79. PMID: 11983154

Gabel, G., J.R. Aschenbacha and F. Muller, 2002. Transfer of energy substrates across the ruminal epithelium: implications and limitations. Anim. Health Res. Rev., 3: 15-30. PMID: 12400867

Goodlad, R.A., 1981. Some effects of diet on the mitotic index and the cell cycle of the ruminal epithelium of sheep. Q J. Exp. Physiol., 66: 487499. PMID: 6914682

Gozho, G.N., J.C. Plaizier, D.O. Krause, A.D. Kennedy and K.M. Wittenberg, 2005. Subacute ruminal acidosis induces ruminal lipopolysaccharide endotoxin release and triggers an inflammatory response. J. Dairy Sci., 88: 1399-1403. PMID: 15778308
Han, Y.P., T.L. Tuan, H. Wu, M. Hughes, W.L. Garner, 2001. TNF-alpha stimulates activation of proMMP2 in human skin through NF-(kappa)B mediated induction of MT1-MMP. J. Cell Sci., 114: 131-139. PMID: 11112697

Kelly, J.M., B.W. Mcbride and L.P. Milligan, 1993. In vitro ouabain-sensitive respiration and protein synthesis in ruminal epithelial papillae of Hereford steers fed either alfalfa or bromegrass hay once daily. J. Anim. Sci., 71: 2799-2808. PMID: 8226383

Keunen, J.E., J.C. Plaizier, L. Kyriazakis, T.F. Duffield and T.M. Widowski et al., 2002. Effects of a subacute ruminal acidosis model on the diet selection of dairy cows. J. Dairy Sci., 85: 33043313. PMID: 12512604

Khafipour, E., D.O. Krause and J.C. Plaizier, 2009. A grain-based subacute ruminal acidosis challenge causes translocation of lipopolysaccharide and triggers inflammation. J. Dairy Sci., 92: 10601070. PMID: 19233799

Li, S., E. Khafipour, D.O. Krause, A. Kroeker and J.C. Rodriguez-Lecompte et al., 2012. Effects of subacute ruminal acidosis challenges on fermentation and endotoxins in the rumen and hindgut of dairy cows. J. Dairy Sci., 95: 294-303. PMID: 22192209

Menke, N.B., K.R. Ward, T.M. Witten, D.G. Bonchev and R.F. Diegelmann, 2007. Impaired wound healing. Clin Dermatol, 25: 19-25. PMID: 17276197

Mentschel, J., R. Leiser, C. Mulling, C. Pfarrer and R. Claus, 2001. Butyric acid stimulates rumen mucosa development in the calf mainly by a reduction of apoptosis. Arch Tierernahr, 55: 85-102, PMID: 12068484

Motoi, Y., T. Oohashi, H. Hirose, M. Hiramatsu and S. Miyazaki et al., 1993. Turbidimetric-kinetic assay of endotoxin in rumen fluid or serum of cattle fed rations containing various levels of rolled barley. J. Vet. Med. Sci., 55: 19-25. PMID: 8461422

Nagaraja, T.G. and E.C. Titgemeyer, 2007. Ruminal acidosis in beef cattle: the current microbiological and nutritional outlook. J. Dairy Sci., 901: 17-38. PMID: 17517750

Garrett, E.F., M.N. Pereira, K.V. Nordlund, L.E. Armentano and W.J. Goodger et al., 1999. Diagnostic methods for the detection of subacute ruminal acidosis in dairy cows. J Dairy Sci., 82: 1170-1178. PMID: 10386303

Pfaffl, M.W., A. Tichopad, C. Prgomet and T.P. Neuvians, 2004. Determination of stable housekeeping genes, differentially regulated target genes and sample integrity: BestKeeper--Excelbased tool using pair-wise correlations. Biotechnol. Lett., 26: 509-515. PMID: 15127793 
Plaizier, J.C., D.O. Krause, G.N. Gozho and B.W. McBride, 2008. Subacute ruminal acidosis in dairy cows: the physiological causes, incidence and consequences. Vet. J., 176: 21-31. PMID: 18329918

Schreml, S., R.M. Szeimies, L. Prantl, M. Landthaler and P. Babilas, 2010. Wound healing in the 21st century. J. Am. Acad. Dermatol., 63: 866-881. PMID: 20576319

Steele, M.A., J. Croom, M. Kahler, O. AlZahal and S.E. Hook et al., 2011a. Bovine rumen epithelium undergoes rapid structural adaptations during grain-induced subacute ruminal acidosis. Am. J. Physiol. Regul. Integ.r Comp. Physiol., 300: 15151523. PMID: 21451145

Steele, M.A., L. Dionissopoulos, O. AlZahal, J. Doelman and B.W. McBride, 2012. Rumen epithelial adaptation to ruminal acidosis in lactating cattle involves the coordinated expression of insulin-like growth factor-binding proteins and a cholesterolgenic enzyme. J. Dairy Sci., 95: 318327. PMID: 22192211
Steele, M.A., G. Vandervoort, O. AlZahal, S.E. Hook and J.C. Matthews et al., 2011b. Rumen epithelial adaptation to high-grain diets involves the coordinated regulation of genes involved in cholesterol homeostasis. Physiol. Genomics, 43: 308-316. PMID: 21245418

Thibault, R., F. Blachier, B. Darcy-Vrillon, P. de Coppet and A. Bourreille et al., 2010. Butyrate utilization by the colonic mucosa in inflammatory bowel diseases: a transport deficiency. Inflamm Bowel. Dis., 16: 684-695. PMID: 19774643

Wang, Z. and L.A. Goonewardene, 2004. The use of MIXED models in the analysis of animal experiments with repeated measures data. Can J. Anim. Sci., 84: 1-11.

Xue, Y., S.F. Liao, K.W. Son, S.L. Greenwood and B.W. McBride et al., 2010. Metabolic acidosis in sheep alters expression of renal and skeletal muscle amino acid enzymes and transporters. J. Anim. Sci., 88: 707-717. PMID: 19820050 